\title{
BIOLEACHING FOR THE RECOVERY OF METALS PEMISAHAN UNSUR LOGAM DENGAN BIOLEACHING
}

\author{
Rita Susilawati \\ Center for Geological Resources \\ JI Soekarno Hatta no 444 Bandung 40254 \\ Email: rita.susilawati@uqconnect.edu.au
}

\begin{abstract}
A simple laboratory experiment has been conducted in order to demonstrate the ability of bacteria to leach the metal elements from insoluble ores or solid substrates. The experiment was conducted in a leaching column that was set up using $5 \mathrm{cc}$ syringe that contained $1 \mathrm{cc}$ of glass wool and $3.5 \mathrm{cc}$ of mine tailings. The basal salt was used as an inoculation media while mine tailing was used as a leaching subject and a source of bacterial leaching. Bacterial leaching was isolated using the most probable number (MPN) technique. Overall, the results of the experiment showed the capability of bioleaching process to recover metals from the mine tailings.
\end{abstract}

Keywords: bacteria, bioleaching, metals

\section{SARI}

Kemampuan bakteri untuk memisahkan unsur-unsur logam (bioleaching) dari tailing diperlihatkan melalui eksperimen sederhana yang dilakukan di laboratorium. Eksperimen dilakukan dengan menggunakan kolom yang dibuat dari syringe berukuran 5cc yang telah diisi oleh 1cc benang kaca dan 3.5cc tailing. Tailing digunakan sebagai objek pemisahan dan juga sumber dari bakteri peluruh logam, sementara garam basal digunakan sebagai media untuk merangsang pertumbuhan bakteri tersebut. Isolasi bakteri pemisah logam yang terkandung dalam tailing dilakukan dengan menggunakan teknik MPN (Most Probable Number). Secara umum, eksperimen yang dilakukan berhasil menunjukkan kemampuan bakteri dalam memisahkan logam-logam yang terkandung dalam tailing.

Kata kunci: bakteri, bioleaching, logam 


\section{MAKALAH ILMIAH}

\section{INTRODUCTION}

In general, bioleaching is a process described as being the use of microorganisms to transform elements (metal) from insoluble ores or solid substrates so that the elements can be extracted from a material when water is filtered through it. In this process, the mobilization of metal ion occurred either directly by the metabolism of leaching bacteria or indirectly by ferric iron $\left(\mathrm{Fe}^{3+}\right)$ that is regenerated from ferrous iron $\left(\mathrm{Fe}^{2+}\right)$ by bacterial oxidation (Escobar et al., 2010). Bioleaching is mainly applied in the recovery of low grade sulfide ores and concentrates, that cannot be processed economically by conventional methods (Suzuki, 2001). Bioleaching is also used as a natural bioremediation control to heavy metal pollution in sulfuric mine waste (Southam \& Beveridge, 1992). A variety of acidophilic and chemoautolithotrophic bacteria such as

Thiobacillus thiooxidans (sulfur) and Thiobacillus ferrooxidans (both iron and sulfur) as well as Leptospirillum ferrooxidans facilitate metal solubilization from solid wastes or other solids (Escobar et al., 2010 ; Suzuki, 2001 ; Mielke et al., 2003). The bacteria can catalyze the oxidation of elemental sulfur or reduced sulfur compounds to sulfuric acid and obtain energy from the oxidation of elemental sulfur or reduced sulfur compound, and cause bioacidification and solubilization of heavy metals (Southam \& Beveridge, 1992). Examples of metals extracted by bioleaching are Copper from Chalcopyrite, Zinc from Sphalerite, Uranium from Uraninite and Gold from gold bearing Arsenopyrite.

Using simple laboratory experiment, the paper aims to demonstrate the capability of bioleaching process to recover metal ions from mine tailings. The paper also discusses several key factors that may need to be considered for optimizing the recovery of metals through bioleaching.

\section{METHODS}

\section{Material}

In this experiment, mine tailings was used as a leaching subject and a source of bacterial leaching. Mine tailings sample was provided by Geomicrobiology Lab at the School of Earth Sciences, University of Queensland, Australia and no information provided about the source location of the tailing. The basal salt was used as an inoculation media, which containing (per $\mathrm{L}$ of deionized water): $0.4 \mathrm{gr}\left(\mathrm{NH}_{4}\right)_{2} \mathrm{SO}_{4}$, 0.1 gr $\mathrm{K}_{2} \mathrm{HPO}_{4}, 0.4$ gr $\mathrm{MgSO}_{4} .7 \mathrm{H}_{2} \mathrm{O}, 0.33$ gr $\mathrm{CaCl}_{2} .2 \mathrm{H}_{2} \mathrm{O}$ and $18 \mathrm{mg} \mathrm{FeSO}_{4} .7 \mathrm{H}_{2} \mathrm{O}$, $\mathrm{pH}$ 2.3. Bioleaching experiment was carried out in a simple leaching column that was set up using $5 \mathrm{cc}$ syringes. The syringe contained $1 \mathrm{cc}$ of glass wool and 3.5 cc of tailings (Figure 1).

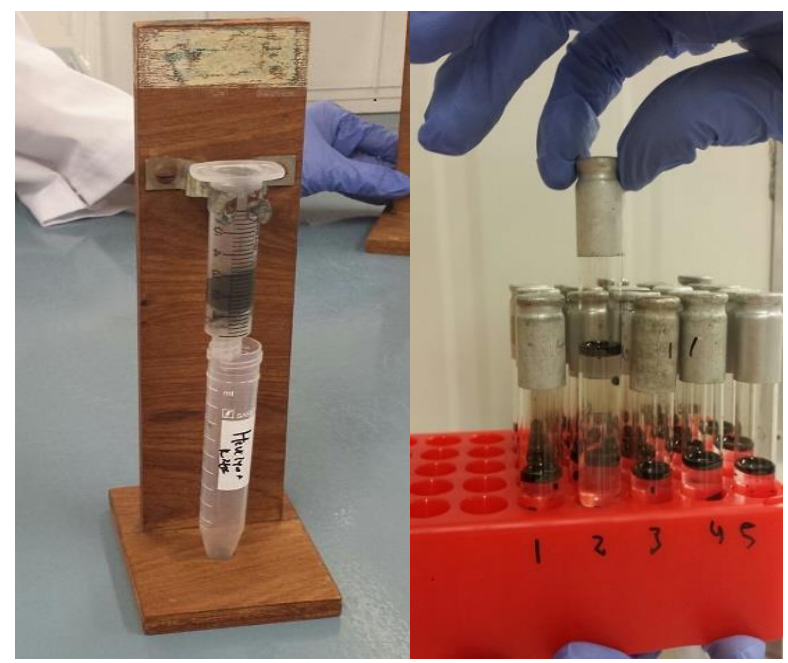

Figure 1. Leaching column for bioleaching experiment (left) and tubes prepared for enumeration of iron oxidizing bacteria (right) 


\section{Enumeration of Bacteria using Most Probable Number (MPN) Method}

In the laboratory, bacterial leaching which are the dominant iron and sulfur oxidizing bacterium from the tailings were isolated using the MPN technique (Cochran, 1950). One gram of mine tailings subjected to tenfold serial dilution $\left(10^{-1}\right.$ to $10^{-5}$ ) and diluted into 5 steriles $16 \times 100 \mathrm{~mm}$ test tubes (with push caps) containing $9 \mathrm{ml}$ of basal salt media. Inoculation was done with transferring $0.5 \mathrm{~mL}$ of each fold dilution into 50 sterile $13 \times 100 \mathrm{~mm}$ test tubes (with push caps), containing $4.5 \mathrm{~mL}$ of basal media. The tubes are then divided into 2 groups. The first 25 tubes prepared for enumeration of iron oxidizing bacteria (e.g: Acidithiobacillus ferrooxidans) where additional $0.5 \mathrm{~mL}$ sterile $\mathrm{FeSO}_{4} 7 \mathrm{H}_{2} \mathrm{O}(33.3$ $\mathrm{gr} / 100 \mathrm{~mL}, \mathrm{pH} 2.3$ ) was added into each tubes as a source of energy. The second group also consist of 25 tubes and prepared for enumeration of sulfur oxidizing bacteria (e.g: Acidithiobacillus thiooxidans ) where a thin film of $S^{\circ}$ was added into each tubes after the bacteria have been inoculated. All culture tubes were then incubated for 2 weeks under stationary conditions at room temperature. At the end of inoculation, tubes were scored for positive growth and iron and sulfur oxidizing bacteria population density was calculated.

\section{Bioleaching Experiment}

Four $\mathrm{mL}$ of basal salts $(\mathrm{pH}=2.3$ ) was added to the bioleaching column (Figure $1)$ at the start of the experiment $(T=0)$ while $2 \mathrm{~mL}$ was added in each subsequent week to promote the growth of iron and sulfur oxidizing bacteria. The column was incubated for 4 weeks in room temperature. The leachate was collected each week for inductively coupled plasma atomic emission spectroscopy (ICP AES) elemental analysis. The $\mathrm{pH}$ of pool leachate was also recorded each week.

\section{Carbonate Analysis}

The amount of carbonates in the tailings was determined using a simple gravimetric procedure as described by Bauer et al. (1972). The method estimates soil capacity to neutralize acid, or to produce $\mathrm{CO}_{2}$ on treatment with acid $(\mathrm{HCl})$, and then calculate the weight of carbonate present on the assumption that it is all present as $\mathrm{CaCO}_{3}$ (Calcite).

\section{RESULTS}

\section{Bacterial Enumeration}

Positive growth was only observed in sulfur oxidizing bacterial tubes (Table 1), while all iron oxidizing bacterial tubes reveal negative results. Using MPN method, it is calculated that the number of sulfur oxidizing bacteria present in the tailings was $90 \mathrm{MPN} / \mathrm{gr}$ of tailings.

Table 1. Result of bacterial enumeration using MPN method

\begin{tabular}{lccccr}
\hline & \multicolumn{6}{c}{ Dilution fold } \\
& $10^{-1}$ & $10^{-2}$ & $10^{-3}$ & $10^{-4}$ & $10^{-5}$ \\
\hline Iron oxidizing bacteria & 0 & 0 & 0 & 0 & 0 \\
$\begin{array}{l}\text { Sulfur oxidizing bacteria } \\
\text { MPN of sulfur oxidizing }\end{array}$ & 4 & 3 & 3 & 4 & 3 \\
bacteria & $0.45 \times 10^{2} \times 2=90$ MPN/gr of tailings \\
\hline
\end{tabular}

\section{Bioleaching Experiment}

In this experiment, the function of the bacteria is to create a chemical environment suitable for metal extraction. In order to figure out the influence of bacteria on leaching chemical environment, the $\mathrm{pH}$ of the leachates was analyzed regularly as well as the metal ion leached each week (Table 2). The amount of Iron and Sulfur in the media added to the column (C2 and $\mathrm{C} 3$ ) was also calculated (Table 3), which are $0.9 \mathrm{ppm}$ and $0 \mathrm{ppm}$ for sulfur and iron respectively. 


\section{MAKALAH ILMIAH}

Tabel 2. ICP EMS results of leachate solution

\begin{tabular}{lrllllllllllll}
\hline \multirow{2}{*}{$\begin{array}{c}\text { Date } \\
\text { collected }\end{array}$} & $\begin{array}{c}\text { Time } \\
\text { (days) }\end{array}$ & \multicolumn{6}{c}{ Composition of the leachate from columns with } & As.45gr tailings (ppm) \\
\hline Aug. 28, 2013 & 0.00 & 7.15 & $\mathbf{C u}$ & $\mathbf{N i}$ & $\mathbf{P b}$ & $\mathbf{Z n}$ & $\mathbf{C a}$ & $\mathbf{F e}$ & $\mathbf{N a}$ & $\mathbf{S}$ & $\mathbf{S i}$ \\
Sept. 4, 2013 & 7.00 & 6.67 & 0.10 & 0.14 & 0.50 & 0.63 & 127.16 & 421.71 & 0.00 & 3476.07 & 5445.37 & 2.61 \\
Sept. 11, 2013 & 14.00 & 5.52 & 0.09 & 0.14 & 0.32 & 0.25 & 59.63 & 469.84 & 0.00 & 162.09 & 1300.58 & 3.55 \\
Sept. 18, 2013 & 21.00 & 6.02 & 0.07 & 0.08 & 0.28 & 0.03 & 50.64 & 511.52 & 0.00 & 70.10 & 943.19 & 3.41 \\
\hline
\end{tabular}

Table 3. Iron and sulfur in media

\begin{tabular}{cccccc}
\hline Element & Media & $\begin{array}{c}\text { \%wt } \\
\text { element }\end{array}$ & C1(ppm) & C2(ppm) & C3(ppm) \\
\hline $\mathrm{Fe}$ & $\begin{array}{c}\mathrm{FeSO} \mathrm{H}_{4} .7 \mathrm{H}_{2} \mathrm{O} \\
\left(18 \mathrm{mg}_{\mathrm{L}}\right)\end{array}$ & 6.50 & 1.17 & 0.00 & 0.00 \\
\hline $\mathrm{S}$ & $\begin{array}{c}\mathrm{MgSO}_{4.7 \mathrm{H}_{2} \mathrm{O}} \\
\left(400 \mathrm{mg}^{2} \mathrm{~L}\right)\end{array}$ & 13.01 & 52.04 & 0.21 & 0.10 \\
\hline $\mathrm{S}$ & $\begin{array}{c}\mathrm{FeSO}_{4.7 \mathrm{H}_{2} \mathrm{O}} \\
\left(18 \mathrm{mg}_{\mathrm{L}}\right)\end{array}$ & 11.53 & 2.08 & 0.01 & 0.00 \\
\hline $\mathrm{S}$ & $\begin{array}{c}\left(\mathrm{NH}_{4}\right)_{2} \mathrm{SO}_{4} \\
(400 \mathrm{mg} / \mathrm{L})\end{array}$ & 24.27 & 97.07 & 0.39 & 0.19 \\
\hline & Total S & & 151.18 & 0.60 & 0.30
\end{tabular}

$\mathrm{C} 1=$ concentration in $1 \mathrm{~L}$ media; $\mathrm{C} 2=$ concentration in $4 \mathrm{~mL}$ media added to the column;

C3= concentration in $2 \mathrm{~mL}$ of media added to the column

Whereas the basal salt media has acidic $\mathrm{pH}$, the leachate at time 0 shows neutral $\mathrm{pH}$. Overall, there is a tendency that the $\mathrm{pH}$ of the leachate decreased, from 7.15 at time 0 to 6.02 at day 21 (Figure 2). During the course of 21 days, $26.71 \%$ of Zinc leached from the column while negligible amount of Arsenic, Copper and Lead recovered from the column (Table 4). Except for Calcium, our data shows the decreasing trend in the amount of elements leached during this experiment (Figure 3). 


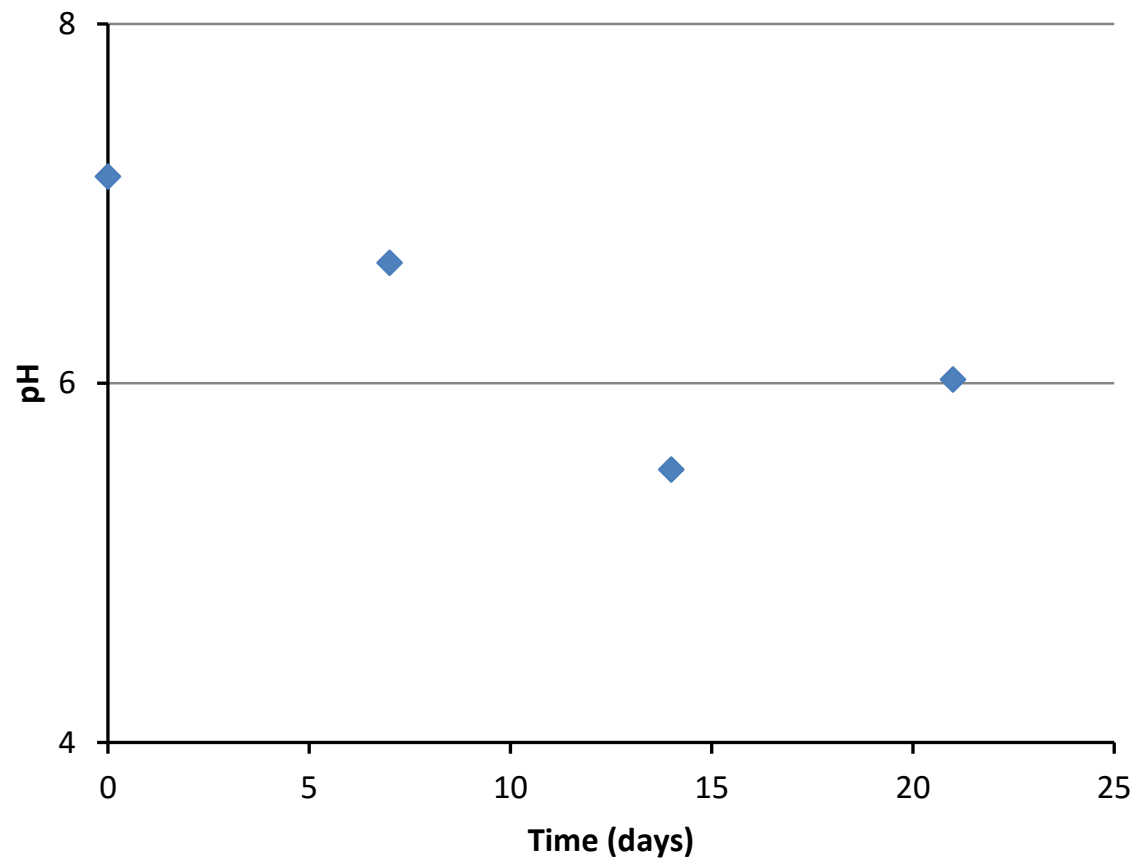

Figure 2. $\mathrm{pH}$ of the leachate monitored during the experiment

Tabel 4. Element leached from $3.45 \mathrm{gr}$ tailings

\begin{tabular}{ccccc}
\hline & As & $\mathrm{Cu}$ & $\mathrm{Pb}$ & $\mathrm{Zn}$ \\
\hline $\begin{array}{c}\text { Original concentration of element in } \\
\text { 3.45 gr tailings (ppm) }\end{array}$ & $\mathbf{1 1 0 0}$ & $\mathbf{4 0 0 0}$ & $\mathbf{9 0 0 0}$ & $\mathbf{1 2 0 0}$ \\
\hline Time (days) & \multicolumn{3}{c}{ Element leached \% } \\
\cline { 2 - 5 } & $\mathbf{A s}$ & $\mathbf{C u}$ & $\mathbf{P b}$ & $\mathbf{Z n}$ \\
\hline 0 & 0.01 & 0.01 & 0.01 & 10.60 \\
7 & 0.01 & 0.00 & 0.00 & 6.93 \\
21 & 0.01 & 0.00 & 0.00 & 4.97 \\
cumulative & 0.01 & 0.00 & 0.00 & 4.22 \\
\hline
\end{tabular}




\section{MAKALAH ILMIAH}

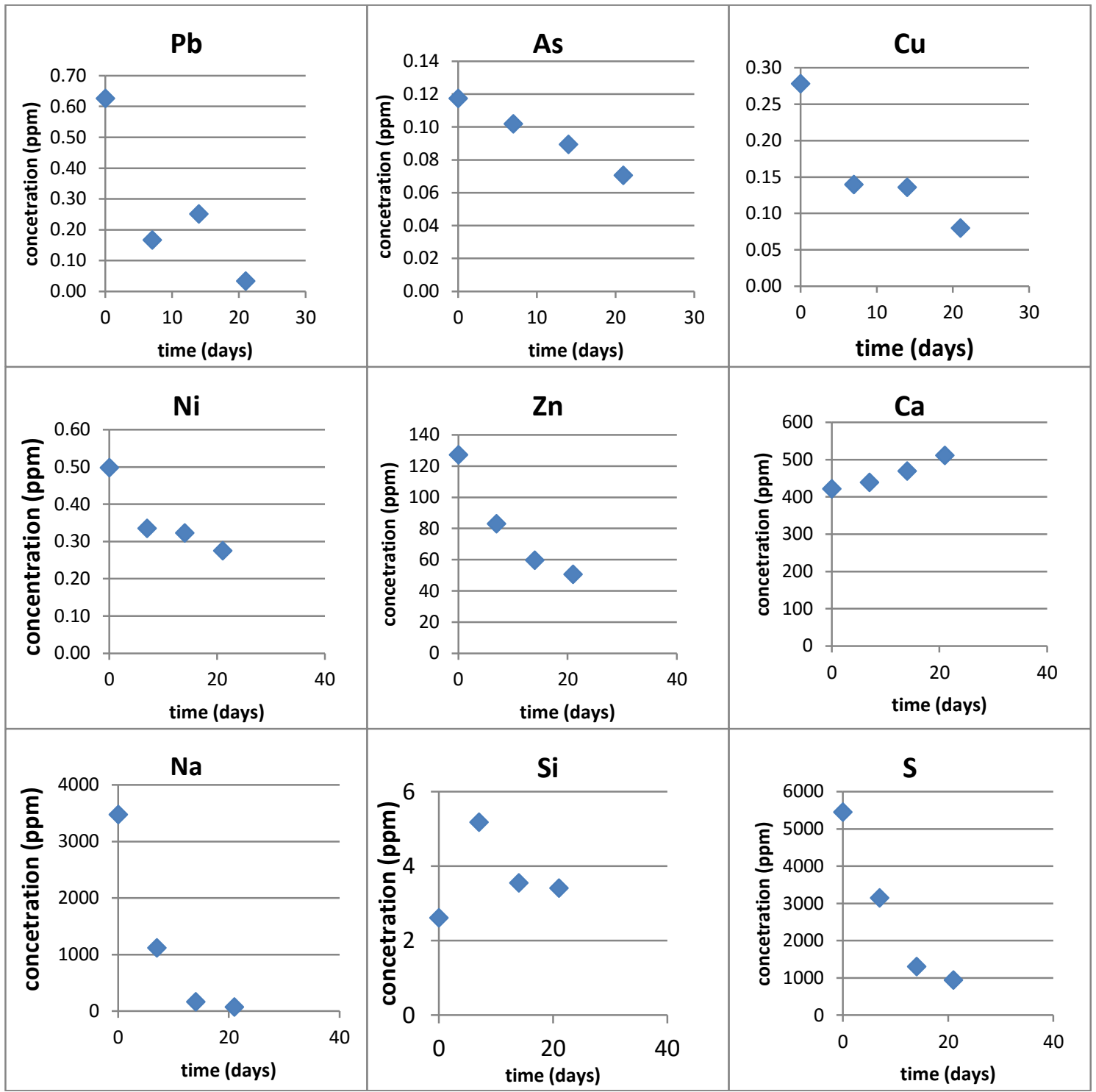

Figure 3. Concentration of elements released from the leachate solution monitored every week

\section{Carbonate Experiment}

The amount of carbonate present in the tailings (with the assumption all carbonate present in the form of $\mathrm{CaCO}_{3}$ ), calculated following the formula (Bauer, 1972):

Weight of $\mathrm{CO}_{2}=\mathrm{W} 2-\mathrm{W} 3$, Percent of $\mathrm{CaCO}_{3}$ equivalent $=(\mathrm{W} 2-$ W3 $) \times$ 227.4/(W2-W1)

where :
W1 = Weight of $\mathrm{HCl}$, beaker and tray

W2 = Weight of $\mathrm{HCl}$, beaker, tray and original tailings

W3 = Weight of $\mathrm{HCl}$, beaker, tray and tailings after being reacted with $\mathrm{HCl}$ for 90 minutes

Based on the above formula, the percentage of carbonate present in the tailings is 31.88 (Table 5). 
Tabel 5. Carbonate analysis

\begin{tabular}{lr}
\hline Original tailings $(\mathrm{mg})$ & 1045.43 \\
\hline W1 $(\mathrm{mg})$ & 28896.94 \\
\hline W2 $(\mathrm{mg})$ & 29942.37 \\
\hline W3 $(\mathrm{mg})$ & 29795.80 \\
\hline \%wt Carbonate & 31.88 \\
\hline
\end{tabular}

\section{Minerals in the tailings}

In this experiment, no XRD analysis conducted to identify mineral present in the tailings. However, the ICP EMS data analysis reveals the presence of some element that may associated with several Sulphides, Oxides, Silicates and Carbonate minerals as listed in Table 6.

Table 6. Possible mineral present in the tailings

\begin{tabular}{llll}
\hline Sulphides & Oxides & Silicates & $\begin{array}{l}\text { Carbonate, Sulphates } \\
\text { and Salts }\end{array}$ \\
\hline Pyrite $\mathrm{FeS}_{2}$ & Hematite $\mathrm{Fe}_{2} \mathrm{O}$ & Quartz $\mathrm{SiO}_{2}$ & Calcite $\mathrm{CaCO}_{3}$ \\
\hline Pyrrhotite $\mathrm{FeS}$ & Limonite $\mathrm{FeO} . \mathrm{OH} . \mathrm{nH}_{2} \mathrm{O}$ & Dolomite $\mathrm{CaMg}_{\left(\mathrm{CO}_{3}\right)_{2}}$ \\
\hline Chalcopyrite CuFeS & & Cerussite $\mathrm{PbCO}_{3}$ \\
\hline Arsenopyrite $\mathrm{FeAsS}$ & & Halite $\mathrm{NaCl}$ \\
\hline Sphalerite $(\mathrm{Zn}, \mathrm{Fe}) \mathrm{S}$ & & Gypsum $\mathrm{CaSO}_{4} \cdot \mathrm{H}_{2} \mathrm{O}$ \\
\hline Galena $\mathrm{PbS}$ & & \\
\hline
\end{tabular}

\section{DISCUSSION}

In this experiment, bacterial enumeration using MPN methods reveals very low concentration of iron oxidizing bacteria. The outcome with all negative tubes in each dilution of iron oxidizing bacteria tubes suggests bacterial count less than $0.18 \mathrm{MPN} / \mathrm{gr}$ of tailings. Low concentration of bacteria, thought to be related to sampling issue. Bacterial mostly attached to its substrate (tailings). Solid particle of the tailings that sank to the bottom of the tubes is more likely has high concentration of bacteria. Inoculum mostly sampled from the middle of the tubes; as such the bacterial concentration in $0.5 \mathrm{~mL}$ inoculum taken from those part possible are very low.

In general, the result of this experiment which is shown by the concentration of the element found in the leachate during the course of 21 days of experiment, as well as the changes of the $\mathrm{pH}$ of the leachate over time, suggest that biogenic process occurred in this column and that chemical reactions is unlikely working alone in this system. The process is explained below.

When tailings sample containing sulfide mineral and its indigenous iron and sulfur oxidizing bacteria is contacted with basal medium $\mathrm{pH}$ 2.3, two possible bioleaching mechanisms can be occurred, which are direct and indirect mechanisms (Sand et al., 2001 ; Suzuki, 2001). In direct mechanism, microorganism will directly oxidize and solubilize metals (reaction 1). In this process, the sulfur is biologically oxidized to sulfate without any detectable intermediate occurring (reaction 2). In contrast, in indirect mechanism, sulfide mineral is oxidized by ferric iron which is regenerated from ferrous iron. Ferrous iron can be generated from pyrite oxidation (reaction 5) and can be re oxidized to ferric iron by iron-oxidizing microorganisms (reaction 4). In this mechanism, microorganism has a role simply in regeneration of ferric iron from ferrous iron. Ferric iron can also be hydrolyzed (reaction 6) and can chemically react with pyrite to generate ferrous iron and elemental sulfur (reaction 7). Under acidic conditions the oxidations of sulfide minerals by iron oxidizing bacteria can be $10^{6}$ times faster than the abiotic rate (Escobar et al., 2010).

a) $\mathrm{MS}+\mathrm{H}_{2} \mathrm{SO}_{4}+1 / 2 \mathrm{O}_{2} \rightarrow \mathrm{M}^{2+}+\mathrm{SO}_{4}+$ $\mathrm{S}^{\circ}+\mathrm{H}_{2} \mathrm{O} \quad \mathrm{M}=$ divalent metal

b) $\mathrm{S}^{0}+3 \frac{1}{2} \mathrm{O}_{2}(\mathrm{ac})+\mathrm{H}_{2} \mathrm{O} \rightarrow \mathrm{SO}_{4}{ }^{2-}+$ $2 \mathrm{H}^{+}$

c) $\mathrm{MS}+2 \mathrm{Fe}^{3+} \rightarrow \mathrm{M}^{2+}+2 \mathrm{Fe}^{2+}+\mathrm{S}^{\circ}$

d) $2 \mathrm{Fe}^{2+}+1 / 2 \mathrm{O}_{2}+2 \mathrm{H}+\rightarrow 2 \mathrm{Fe}^{3+}+$ $\mathrm{H}_{2} \mathrm{O}$ 
e) $2 \mathrm{FeS}_{2}+3 \mathrm{O}_{2}(\mathrm{ac})+2 \mathrm{H}_{2} \mathrm{O} \rightarrow$ $2 \mathrm{FeSO}_{4}+2 \mathrm{H}_{2} \mathrm{~S}$ chemical reaction

f) $\mathrm{Fe}^{+3}+3 \mathrm{H}_{2} \mathrm{O} \rightarrow \mathrm{Fe}(\mathrm{OH}) 3(\mathrm{~s})+3 \mathrm{H}^{+}$ chemical reaction

g) $\mathrm{Fe} \mathrm{S}_{2}(\mathrm{~s})+\mathrm{Fe}_{2}\left(\mathrm{SO}_{4}\right)_{3} \rightarrow 3 \mathrm{Fe}{ }^{2+}+$ $3 \mathrm{SO}_{4}+2 \mathrm{~S}^{\circ}$ chemical reaction

The $\mathrm{pH}$ of the column decrease from time 0 to day 14 , however on day 21 the $\mathrm{pH}$ is slightly increase. Overall, during the experiment the $\mathrm{pH}$ of the column stand in the range of 5 to 7 . The decreasing $\mathrm{pH}$ indicates that acid was generated in the column. The oxidations of ferrous iron to ferric iron increase the ferric iron concentration. As ferric iron accumulates, hydrolyses occurred and acid produced which further lower the $\mathrm{pH}$ of the column environment (reaction 6). Acid can also be produced from sulfur oxidation (reaction 2). The increase of the $\mathrm{pH}$ at day 21 is likely caused by accumulation of ferrous iron, which consumes a lot of acid to produce ferrous iron (reaction 4). The occurrence of carbonate mineral in the tailings, which is quite significant $(31.88 \%)$, is also thought to act as a buffer which may prevent further acidic condition of the column. Carbonate minerals may form protective layer on mineral surface that can decrease the metal dissolution process (Deveci et al., 2003). Study has noticed that the occurrence of carbonate minerals such as Calcite $\left(\mathrm{CaCO}_{3}\right)$, Dolomite $\quad\left[\mathrm{CaMg}(\mathrm{CO})_{2}\right]$ Ankerite $\left[\mathrm{Ca}(\mathrm{Fe}, \mathrm{Mg})(\mathrm{CO} 3)_{2}\right]$ and Siderite $\left(\mathrm{FeCO}_{3}\right)$ in sulfide bearing mineral deposit can help to prevent the formation of low $\mathrm{pH}$ drainage from the waste contaminant area (Al et al., 2000).

In this experiment, almost no Iron was found in the leachate, suggesting that Iron was heavily used in the oxidation process of other mineral. As significant amount of Zinc found in the leachate, it is quite likely that Iron was used for the oxidation of Sphalerite. Furthermore, among other element, Sulfur concentration in the leachate is the greatest, even after Sulfur from the media has been taken into account (Table 3), suggesting that a lot of Sulfur produced during the biosolubilization of metal sulfide (reaction
3). On the other hand, the increasing $\mathrm{Ca}$ concentration in the leachate solution each week was thought to be related to the $\mathrm{pH}$ of the leachate. The decreasing of $\mathrm{pH}$ was likely increase the solubility of $\mathrm{Ca}$. Study on $\mathrm{Ca}$ and $\mathrm{Mg}$ concentrations in the leachate from permanent meadow soils in Western Lithuania also showed the same phenomena where $\mathrm{Ca}$ solubilization increased with decreasing $\mathrm{pH}$ (Butkute $\mathrm{R}$, 2006).

Negligible amount of Lead, Arsenic and Copper leached from the column (Table 2 ), suggest that the low concentration of Iron and Sulfur oxidizing bacterial in the column are too low to drive the bioleaching process of all base metal in the tailings. Bacterial leaching is very important to accelerate the metal leaching. For instance, the Copper solubilization has increase significantly when more stock culture added to the bioleaching system, suggesting that the large amount of bacteria can accelerate the Copper leaching (Yang et al., 2009). It should be noted that the ferrous ion can also be oxidized to ferric ion only by oxygen from air, but this process was very slow (Yang et al., 2009). The poor solubilization of Lead is common, as under bioleaching condition, Lead forms Anglesite $\left(\mathrm{PbSO}_{4}\right)$, a poorly soluble complex with sulfate which tend to accumulates in residual solid (Viera et al., 2007).

The $\mathrm{pH}$ of the column is also thought not favorable for optimal growth of microbial leaching which then slow the bioleaching process. The optimum $\mathrm{pH}$ for the growth of acidophilic bacteria involved in bioleaching ranges from 1.5 to 3.0. High proton concentration is needed to drive certain chemical reactions during bioleaching which can only be provided if the $\mathrm{pH}$ maintained to be acidic. Additionally, high precipitation of Jarosite may also occur in $\mathrm{pH}$ over 2.0. Jarosite has been known can influence the mechanisms of Copper extraction from the ores during bioleaching process (Gentina and Acevedo, 2003). Acid neutralization by carbonate minerals may also cause a reduction in the concentration of dissolved metals (Al et 
al., 2000). In neutral $\mathrm{pH}$, metals partition from the aqueous phase to mineral surfaces mostly occurred due to precipitation, co-precipitation and adsorption processes (Al et al., 2000). As the surfaces of carbonate minerals are highly reactive, the concentration of dissolved metals in the system will be influenced by co-precipitation and adsorption reactions at carbonate mineral surfaces (Al et al., 2000).

In this experiment, considerably higher concentration of Zinc is also observed in the leachate. Approximately $27 \%$ of Zinc leached during 21 days of experiment. Within this condition, all Zinc in $3.45 \mathrm{gr}$ tailings can be expected to solubilize in approximately 79 days. The higher solubilization rate of Zinc compare to other elements is thought to be related to sulfide mineral electrode potential. Sulfide minerals vary in susceptibility to bio oxidation (Olson et al., 2003). Dissolution of metal sulfides depends on their electrochemical potential. The mineral with the lowest potential tends to oxidize first (Olson et al., 2003). Study noticed that sulfides mineral like Sphalerite (ZnS) have low electrode potentials which make this mineral readily bio oxidized (Olson et al., 2003). However, it is observed that the concentrations of Zinc leached from the column decrease over time. Study noticed that when zinc sulfide is oxidized by ferric ions, a product layer of elemental sulfur is formed on the surface of the mineral and the diffusion of ferrous ions across this sulfur layer becomes the rate-limiting step (Viera et al., 2007). In the absent of sulfur oxidizing bacteria, the passivation of the Sphalerite surface by a layer of elemental sulfur may slow the leaching process, however in the presence of sulfur oxidizing bacteria this condition may remain occurred if the rate of elemental sulfur oxidation is inadequate (Viera et al., 2007). The decreasing concentration of sulfur leached overtime in this experiment, occurred as some sulfur possibly layered the surface of mineral as explained above. To increase the recovery of Zinc during bioleaching of sulfides ores, Saririchi et al. (2012) has suggested to do the continuous inoculation of the ores with the solution of A. ferrooxidans type which should be maintained until the bioleaching process become self-sustaining.

Finally, in order to achieve optimum performance of the bioleaching column in this experiment, several factors should be taken into account. These factors are temperature, acidity, oxidizing conditions, availability of nutrients, oxygen and carbon dioxide as well as surface area and presence of toxic ions (Deveci et al., 2003).

Bioleaching processes are temperature and $\mathrm{pH}$ dependent, with optimum metal dissolution occurring in a particular range where the bacterial strain is most active. The acidity of the bioleaching environment is possibly controlled by the oxidation of iron, sulfur and metal sulfides as well as dissolution of carbonate minerals (Kumar \& Nagendran, 2007 ; Suzuki, 2001). The optimum growth of the bacteria can be maintained with provision of nutrient salts. Metal dissolution will also depend to the quantity of nutrients and the availability of substrate (Olson et al., 2003 ; Saririchi et al., 2012 ; Viera et al., 2007 ; Yang et al., 2009).

Most bacterial leaching are autotrophic aerobes. The activity of these bacteria depends largely on the availability of oxygen and $\mathrm{CO}_{2}$ which are important to complete the cycle of they respiration. The oxygen levels below 1-2 mg/L can negatively affect the oxidizing activity of bacteria (Deveci et al., 2003). The surface area (particle size) may improve the bioleaching rate while increasing concentrations of ions such as $\mathrm{Cl}^{-}$may also negatively affect the oxidative activity of bacteria (Viera et al., 2007). High concentration of $\mathrm{Ag}$, anions of $\mathrm{Te}$, As and Se $(50-100 \mathrm{mg} / \mathrm{L})$ has been proven to have inhibitory effect on the iron oxidizing activity of the bacteria (Deveci et al., 2003). Moreover, the salinity of process water may also suppress the bioleaching activity of mesophilic bacteria (Deveci et al., 2003). In addition, mineral species as well as ore composition and structure also 
affect the rate and extension of the metal extraction by bioleaching from reduced sulfur compounds. For instance, the secondary copper minerals are easier to bioleach than the primary ones (Gentina and Acevedo, 2003).

\section{CONCLUSIONS}

This experiment has demonstrated the capability of bioleaching process for recovery of metals from the tailings. While the amount of Lead, Arsenic and Copper leached from the column are negligible, significant amount of Zinc leached from the column. Low concentration of iron and sulfur oxidation bacteria in the inoculum thought to be the major factor that suppresses the bioleaching activity in this experiment. Adding more microbial leaching or nutrient to the column, may increase the performance of the bioleaching column. It is also important to maintain the $\mathrm{pH}$ to be in the range of 1.5 to 2. Other than nutrient and $\mathrm{pH}$, temperature, oxidizing conditions, oxygen and carbon dioxide, surface area as well as the presence of toxic ions are several key factors that may need to be considered for optimizing the recovery of metals through bioleaching process.

\section{ACKNOWLEDGMENT}

The experiment reported in this paper is part of Geomicrobiology course taught at the School of Earth Sciences, University of Queensland, Australia in 2013. Thanks to Evelyn my geomicrobe lab partner and Maija my lab supervisor. The author also thanks the editor for their constructive reviews to the paper.

\section{REFERENCES}

Bauer HP, Beckett PHT, Bie SW (1972) A rapid gravimetric method for estimating calcium carbonate in soils. Plant Soil, 37, 689-690.

Butkute, R (2006) Calcium and magnesium concentrations in the leachate from permanent meadow soils. Grassland Science in Europe, 11, 718-720.
Cochran WG (1950) Estimation of Bacterial Densities by Means of the "Most Probable Number". Biometrics, 6, 105-116.

Deveci H, Akcil A, Alp I (2003) Parameters for control and optimization of bioleaching of sulfide minerals. In: Process control and optimization in Ferrous and Non Ferrous Indusry (eds Kongoli F, Sawamiphad K), Turkey.

Escobar B, Buccicardi S, Morales G, Wiertz J (2010) Biooxidation of ferrous iron and sulphide at low temperatures: Implications on acid mine drainage and bioleaching of sulphide minerals. Hydrometallurgy, 104, 454-458.

Kumar RN, Nagendran R (2007) Influence of initial $\mathrm{pH}$ on bioleaching of heavy metals from contaminated soil employing indigenous Acidithiobacillus thiooxidans. Chemosphere, 66, 1775-1781.

Mielke R, ., Pace D, Porter .T, G S (2003,) A critical stage in the formation of acid mine drainage: colonization of pyrite by Acidithiobacillus ferrooxidans under $\mathrm{pH}$-neutral conditions. Geobiology, 1, 81-90.

Olson GJ, Brierley JA, Brierley CL (2003) Bioleaching review part B. Appl Microbiol Biotechnol, 63, 249-257.

Sand W, Gehrke T, Jozsa P-G, Schippers A (2001) (Bio)chemistry of bacterial leaching-direct vs. indirect bioleaching. Hydrometallurgy, 59, 159-175.

Saririchi T, Azad RR, Arabian D, Molaie A, Nemati $F$ (2012) On the optimization of sphalerite bioleaching; the inspection of intermittent irrigation, type of agglomeration, feed formulation and their interactions on the bioleaching of low-grade zinc sulfide ores. Chemical Engineering Journal, 187, 217-221.

Southam G, Beveridge T (1992) Enumeration of thiobacilli within $\mathrm{pH}-$ neutral and acidic mine tailings and their role in the development of secondary mineral soil. Applied and environmental microbiology, 58, 1904-1912. 


\section{MAKALAH ILMIAH}

Suzuki I (2001) Microbial leaching of metals from sulfide minerals. Biotechnology Advances, 19, 119132.

Viera M, Pogliani C, Donati E (2007) Recovery Of Zinc, Nickel, Cobalt And Other Metals By Bioleaching. In: Microbial Processing of Metal
Sulfides (eds Donati E, Sand W). Springer Netherlands, pp. 103-119.

Yang T, Xu Z, Wen J, Yang L (2009) Factors influencing bioleaching copper from waste printed circuit boards by Acidithiobacillus ferrooxidans. Hydrometallurgy, 97, 29-32.

$\begin{array}{ll}\text { Diterima } & : 13 \text { Agustus } 2015 \\ \text { Direvisi } & : 9 \text { Oktober } 2015 \\ \text { Disetujui } & : 10 \text { November } 2015\end{array}$

